\title{
A Continuous Health Monitoring System for Photovoltaic Array Using Arduino Microcontroller
}

\author{
P. Pounraj1, D. Prince Winston ${ }^{2}$, S. Cynthia Christabel ${ }^{3}$, R. Ramaraj ${ }^{4}$ \\ ${ }^{1}$ Department of Electrical and Electronic Engineering, Cheran College of Engineering, Karur, India \\ ${ }^{2}$ Department of Electrical and Electronic Engineering, Kamaraj College of Engineering and Technology, Virudhunagar, India \\ ${ }^{3}$ Department of Electrical and Electronic Engineering, Sethu Institute of Technology, Kariapatti, India \\ ${ }^{4}$ Kamaraj College of Engineering and Technology, Virudhunagar, India \\ Email: eeepounrajssce@gmail.com,dpwtce@gmail.com, scynthiaprince@gmail.com,ramarajkcet@gmail.com
}

How to cite this paper: Pounraj, P., Prince Winston, D., Cynthia Christabel, S. and Ramaraj, R. (2016) A Continuous Health Monitoring System for Photovoltaic Array Using Arduino Microcontroller. Circuits and Systems, 7, 3494-3503.

http://dx.doi.org/10.4236/cs.2016.711297

Received: April 13, 2016

Accepted: May 5, 2016

Published: September 7, 2016

Copyright $\odot 2016$ by authors and Scientific Research Publishing Inc. This work is licensed under the Creative Commons Attribution International License (CC BY 4.0).

http://creativecommons.org/licenses/by/4.0/

\begin{abstract}
In this paper new technique is developed to monitor the health status of the PV panels in the array. For finding the health status short circuit current is measured continuously over a fixed time period. This technique can classify the health status into four categories such as Healthy, Low Fault, Medium Fault and High Fault. By this classification faulty operation can be rectified and power generation may be improved. In case of high faults, PV panels can be protected. The cost requirement for the implementation is very low. The proposed technique is implemented in MATLAB Simulation and hardware. The array considered in this paper is $2 \times 2 \mathrm{Se}-$ ries Parallel.
\end{abstract}

\section{Keywords}

Photovoltaic (PV) Array, Health Monitoring, Fault, Arduino Microcontroller

\section{Introduction}

The increasing power requirements for almost all application areas and disadvantages of the conventional energy sources like pollution, limited amount, etc. in today's world have attracted the attentions of the solar PV and meeting the power requirements using solar energy as one of the mentioned renewable energy sources has been considered by many researchers. The photovoltaic (PV) generation system is increasing rapidly and showing an industrial growth of approximately $45 \%$ per year worldwide [1] [2]. This has resulted in an increased demand for knowledge of PV devices and system performances. The development of smart grid concept has acted as a catalyst for wide-spread penetration of PV systems. PV systems are expected to play a major role in smart grids 
as a distributed generation (DG) or as a power plant. PV systems are well-known as an important factor in reducing greenhouse gases and in securing the availability of energy in the future [3] [4].

Photovoltaic (PV) power generators convert the energy of solar radiation directly to electrical energy without any moving parts. PV power generators can be classified into stand-alone and grid-connected generators. In stand-alone systems, the energy storage has big influence on the design of the systems. In grid-connected systems, the grid acts as an energy storage into which the PV power generator can inject power whenever power is available. The electrical grids have specific voltage levels. They are much higher than the maximum voltage of single silicon based PV cell [5]-[7]. In order to interface PV power generators with the grid, the PV cells are connected in series to form PV modules. Solar photovoltaic (PV) energy has been widely utilized in small-sized applications. It is also the most promising candidate for research and development for large-scale uses as the fabrication of less-costly photovoltaic devices becomes a reality. Applications of PV systems include water pumping, domestic and street lighting, electric vehicles, hybrid systems, military and space applications, refrigeration and vaccine storage, power plants, etc., all in either stand-alone or grid-connected configurations [8]-[10]. A PV system is generally composed of PV modules and balance of system (BOS) components. The BOS components include the array structure, passive or active trackers, connectors, ac and dc wiring, over current protections, disconnects, interconnects, inverters, charge controllers, MPPT controllers, energy storage devices, and system controllers. Storage devices are necessary in many PV installations, not only in stand-alone systems but also in grid-connected PV systems with critical loads, such as in the telecommunication, medical, and industrial control systems, to which a continuous and high-quality power must be ensured.

Although a variety of energy storage methods are under consideration, the majority of PV systems today use battery storage. The most commonly used batteries are lead acid ones because of their good availability and cost effectiveness; the nickel (Ni-Cd or $\mathrm{Ni}-\mathrm{HD})$ types are gaining increased acceptance for portable applications and in environments with extreme temperature variations, particularly cold [11] [12]. Batteries have to be properly managed to obtain maximum life since life reduction due to misuse can sharply increase costs and strongly affects the reliability of the whole PV system. In typical stand-alone PV systems suitable ampere-hour counting algorithms can improve battery cycle life, lower maintenance costs, and reduce PV system life-cycle costs.

However relatively high installation costs, lack of economically efficient energy storage devices and relatively low efficiencies have formed the disadvantages of this huge energy source. However, for an efficient use of solar energy, having a precise knowledge of the amount of power yield of each individual photovoltaic generator under different conditions carries a great importance during system design procedures. The output characteristics of solar cells strongly depend on the changing environmental conditions (e.g. irradiance, temperature etc.) and the cell/module interconnection types.

A critical element for a large spreading of the PV technology is the low value of the 
cell efficiency. This value ranges from 5\% to $17 \%$ for commercial PV-cell until $25 \%$ for laboratory applications in conditioned environment. This low value of the efficiency is strongly affected by the temperature. In fact, the optimal performances of the PV-cell are reached only if the operating temperature of the PV-cell is just equal to the NOCT (Nominal Operating Cell Temperature) defined by the rating [13] [14]. A $10^{\circ} \mathrm{C}$ increase of the cell temperature causes about $4 \%$ power loss (so called light), while a $18^{\circ} \mathrm{C}$ increase determines about $10 \%$ power loss (so called strong). These values of power losses cannot be accepted in system having so low efficiency values.

\section{Problems Definition}

The power output of the PV panel varies directly proportional to the irradiation and inversely proportional to the temperature. The output power increases with decrease in temperature and decreases with increase in temperature. During the temperature increase, current increases and voltage decreases and the net power decreases. Some faults in the PV panel can vary the temperature of the panel and some others can't. So, fault identification by temperature analysis alone as well as by short circuit analysis alone is not efficient, since the current varies with temperature rise.

\section{Proposed Method}

Define abbreviations and acronyms the first time they are used in the text, even after they have been defined in the abstract. Abbreviations such as IEEE, SI, MKS, CGS, sc, $\mathrm{dc}$, and rms do not have to be defined. Do not use abbreviations in the title or heads unless they are unavoidable.

In the proposed method fault levels are identified by using both temperature and short circuit current values. For every 30 minutes, from morning 6.00 am to evening $6.00 \mathrm{pm}$ temperature and short circuit current values are measured for each panel. The measured temperature and current values are compared with the reference and also within the same array groups. For measuring the temperature LM35 is used and for measuring the current, ACS712 module is used.

The specifications of the PV panel used in work are

$$
\begin{aligned}
& V_{o c}=21.9 \mathrm{~V} \\
& I_{s c}=0.59 \mathrm{~A} \\
& V_{m}=18.25 \\
& I_{m}=0.55 \mathrm{~A} \\
& P_{\max }=10 \mathrm{~W}
\end{aligned}
$$

\subsection{Modeling of PV Panels in MATLAB Simulink}

For the proposed system, $2 \times 2$ solar PV module is used. Each module is of $10 \mathrm{~W}$ power rating and under Standard Testing Condition (STC), that is $1000 \mathrm{~W} / \mathrm{m}^{2}$ of irradiance at $25^{\circ} \mathrm{C}$, it has the open circuit voltage ( $\left.V_{o c}\right)$ of $21.96 \mathrm{~V}$ and the short circuit current $\left(I_{s c}\right)$ of $0.59 \mathrm{~A}$. The PV array is composed of PV modules connected in series and parallel in order to obtain the desired voltage and current. The two PV modules in each leg are 
connected in series and the two legs are connected in parallel. The maximum output current and voltage of the PV are 1.1 A and 36.5 V respectively. By knowing these values, the mathematical model of a PV module is framed by using below equations.

$$
\begin{aligned}
& V_{m}^{\prime}=\left\{0.2\left(\frac{S}{1000}-1\right)+1\right\} *\left\{0.00288\left(0.03 S+T_{\text {amb }}-T_{\text {ref }}\right)+1\right\} * V_{m} \\
& V_{o c}^{\prime}=\left\{0.2\left(\frac{S}{1000}-1\right)+1\right\} *\left\{0.00288\left(0.03 S+T_{\text {amb }}-T_{\text {ref }}\right)+1\right\} * V_{o c} \\
& I_{m}^{\prime}=\frac{S I_{m} *\left\{1+0.0025\left(0.03 S+T_{\text {amp }}-T_{\text {ref }}\right)\right\}}{1000} \\
& I_{s c}^{\prime}=\frac{S I_{s c} *\left\{1+0.0025\left(0.03 S+T_{\text {amp }}-T_{\text {ref }}\right)\right\}}{1000}
\end{aligned}
$$

where, $V_{o c}$ and $I_{s c}$ are the open circuit voltage and short circuit current of the PV module respectively. $V_{m}$ and $I_{m}$ are the maximum output voltage and current from the PV module respectively. (1), (2), (3) and (4) are equations used for the modeling of PV module in MATLAB/SIMULINK.

\subsection{Characteristics of PV's}

Photovoltaic's have nonlinear characteristics, where the performance and output power are directly affected with the change of the operating conditions (temperature and solar irradiance). Under STC, the proposed model produces the maximum power of $40 \mathrm{~W}$ which is clearly shown in the PV curve Figure 1 . Table 1 is used to find the temperature variation index. In the proposed work new Short Circuit Current Variation Index (SCCVI) is introduced to find the health status.

$$
\text { SCCVI }=\left(\left(M_{s c} * T_{p}\right)-T_{s c}\right) /\left(M_{s c} * T_{p}\right)
$$

$M_{s c}=$ Maximum short circuit current out of all panels in the array

$T_{p}=$ Total panels in the array

$T_{s c}=$ Total short circuit current of all the panels
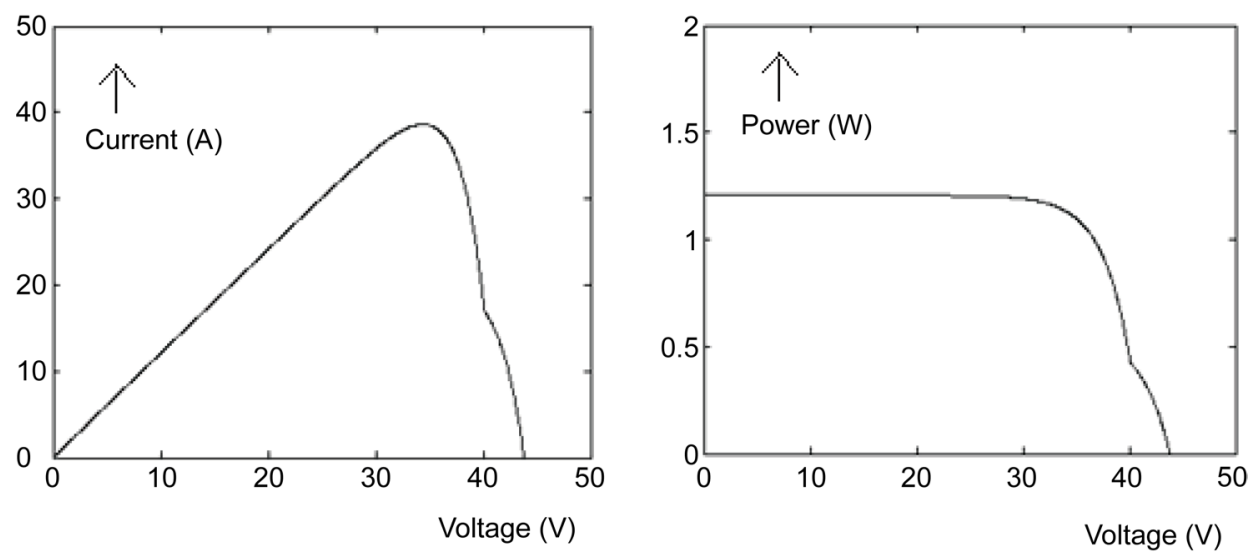

Figure 1. PV and IV curve of proposed model at STC. 
Temperature Variation Index (TVI)

$$
T V I=\left(\left(M_{t} * T_{p}\right)-T_{t}\right) /\left(M_{t} * T_{p}\right)
$$

$M_{t}=$ Maximum temperature out of all panels in the array

$T_{p}=$ Total panels in the array

$T_{t}=$ Total temperature of all the panels

First TVI is calculated, if TVI is greater than 0.1 then health status will be high fault, if it is lesser than 0.1 then SCCVI is calculated and health status is found using Table 2. Table 3 shows the health status when TVI $<0.1$. Figure 2 shows the simulink diagram

Table 1. Temperature variation index.

\begin{tabular}{cc}
\hline TVI & Health Status \\
\hline TVI $<0.1$ & Check the SCCVI \\
$0.1<$ TVI $<1.0$ & High Fault \\
\hline
\end{tabular}

Table 2. Short circuit current variation index.

\begin{tabular}{cc}
\hline SCCVI & Health Status \\
\hline 0 & Healthy \\
SCCVI $<0.1$ & Low Fault \\
$0.1<$ SCCVI $<0.2$ & Medium Fault \\
$0.2<$ SCCVI $<1.0$ & High Fault \\
\hline
\end{tabular}

Table 3. Health status when TVI $<0.1$.

\begin{tabular}{ccc}
\hline Panel Number & Isc (A) & Health Status \\
\hline P1 & 0.59 & \\
P2 & 0.59 & Healthy \\
P3 & 0.59 & \\
P4 & 0.59 & \\
P1 & 0.59 & Low Fault \\
P2 & 0.39 & \\
P3 & 0.59 & \\
P4 & 0.59 & Medium Fault \\
P1 & 0.59 & \\
P2 & 0.39 & \\
P3 & 0.29 & High Fault \\
P4 & 0.59 & \\
P1 & 0.59 & \\
P2 & 0.19 & \\
P3 & 0.29 & \\
P4 & 0.19 & \\
P1 & 0.49 & \\
P2 & 0.10 & \\
P3 & 0.25 & \\
P4 & 0.20 & \\
\hline
\end{tabular}




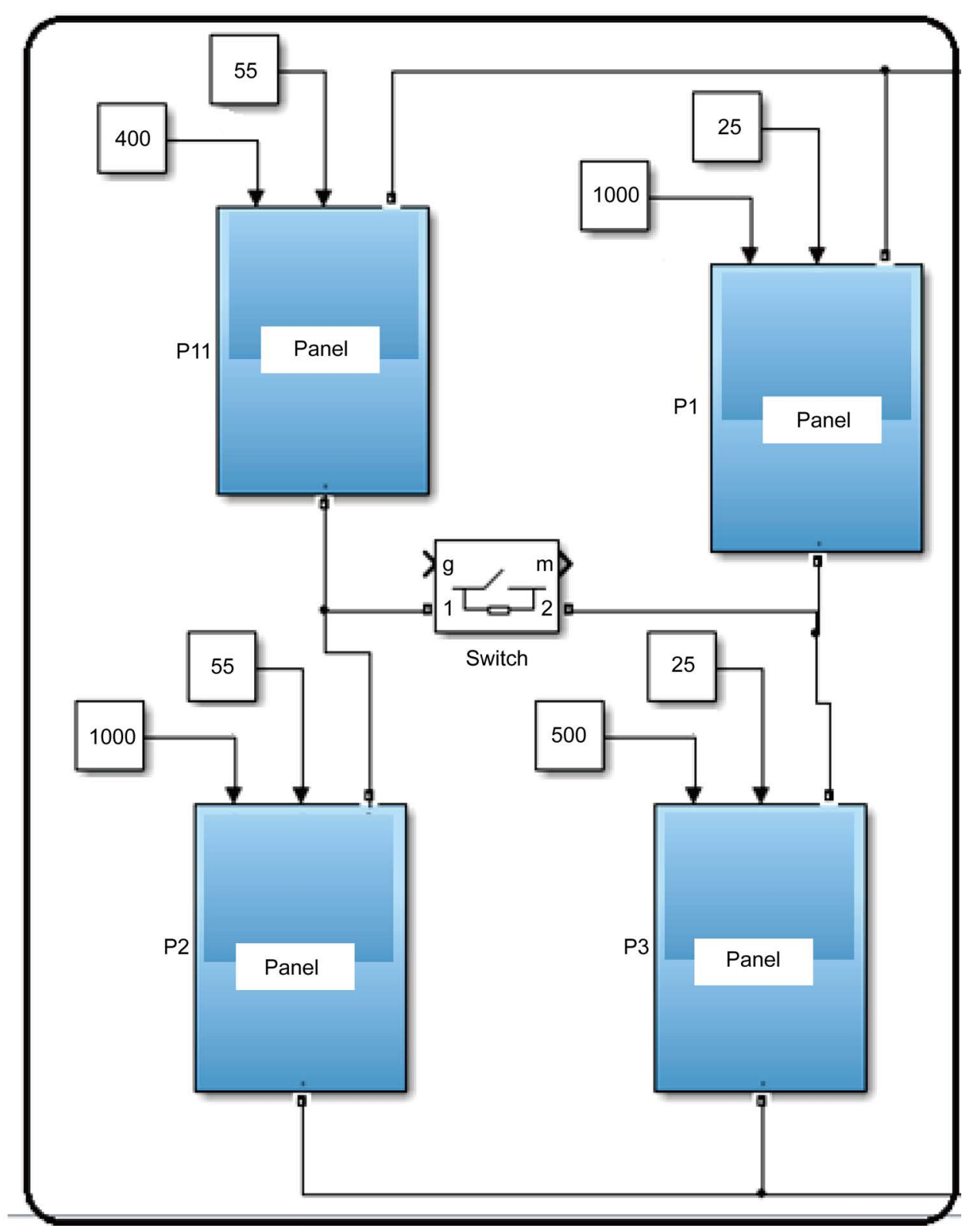

Figure 2. Simulink diagram of the PV system.

of the PV system. Figure 3 shows the block diagram of the proposed System. Figure 4 shows the block diagram of the reconfigured system with IGBT control switch. Figure 5 shows the experimental setup of the proposed system.

Various faults are created by varying the irradiation and temperature of each panel and the corresponding powers are tabulated in Table 4. Figure 6 shows the comparison of results between existing and proposed. In the proposed system after identifying the faulty conditions (low/medium) by using the reconfigured system, the power loss is minimized by turn on the RCS. Similarly, the proposed system can be reconfigured as Series Parallel, Total Cross Tied, Honey Comb, Bridge Link and Su Du Ku. In simulation, partial shading fault is created by varying the irradiation of the panels in the array. 


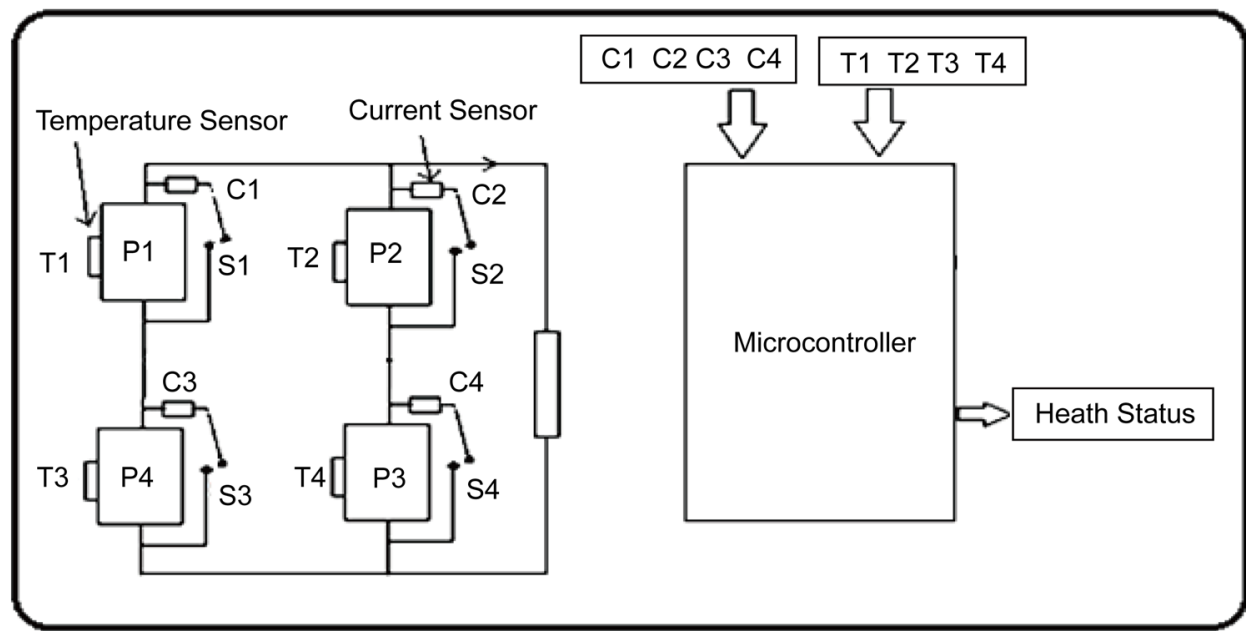

Figure 3. Block diagram of the proposed system.

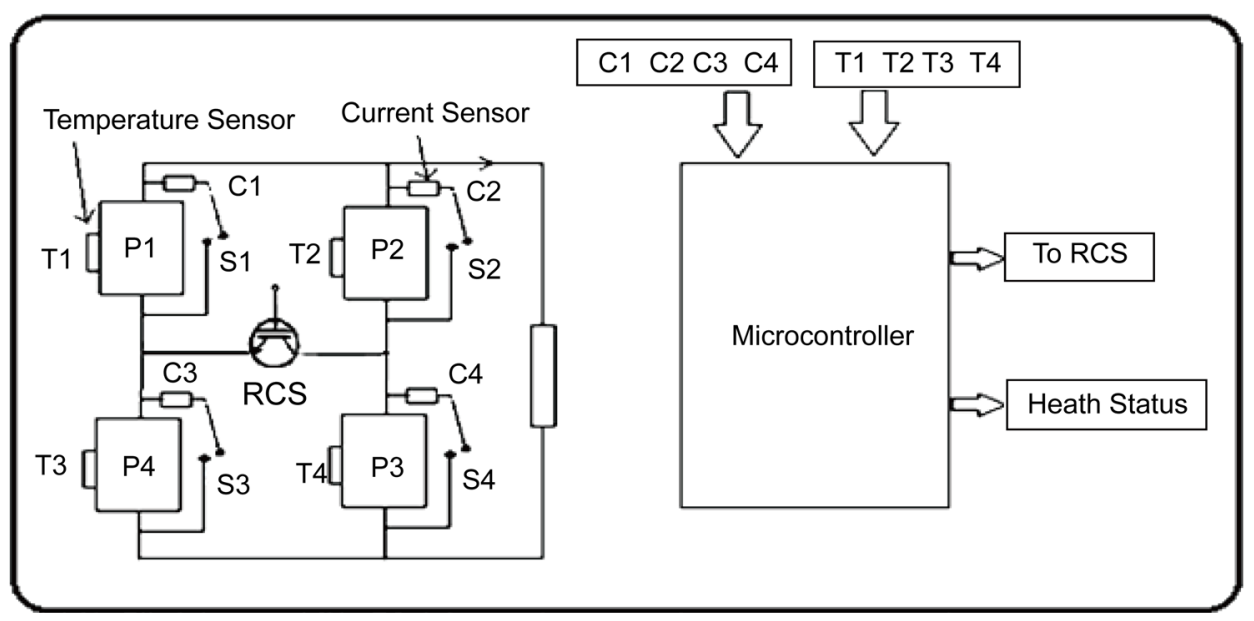

Figure 4. Block diagram of the reconfigured system with IGBT control switch.

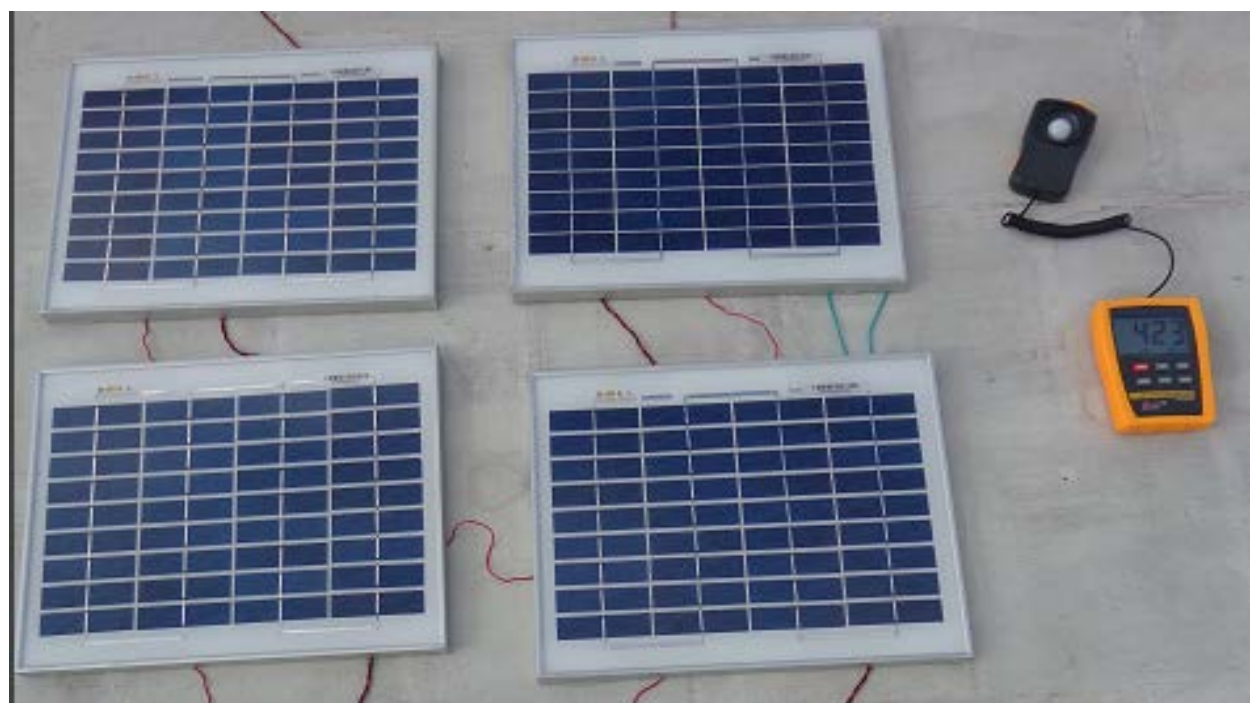

Figure 5. Experimental setup. 
Table 4. Comparison of power generation of proposed reconfigured system.

\begin{tabular}{ccccc}
\hline \multirow{2}{*}{ Type of fault } & \multicolumn{2}{c}{ Before reconfiguration output power $(\mathrm{W})$} & \multicolumn{2}{c}{ After reconfiguration output power (W) } \\
\cline { 2 - 5 } & Simulation & Hardware & Simulation & Hardware \\
\hline Low & 32.1 & 32.6 & 37.1 & 37.1 \\
Medium & 17.3 & 17.5 & 27.3 & 27.6 \\
Low & 30.2 & 30.6 & 34.1 & 35.1 \\
Medium & 14.8 & 15.5 & 23.2 & 24.4 \\
Low & 27.7 & 28.5 & 32.1 & 33.2 \\
Medium & 12.6 & 13.1 & 21.1 & 20.3 \\
Medium & 16.8 & 16.5 & 24.2 & 25.4 \\
Low & 29.7 & 28.6 & 31.2 & 32.3 \\
Medium & 11.6 & 12.3 & 20.1 & 19.8 \\
\hline
\end{tabular}

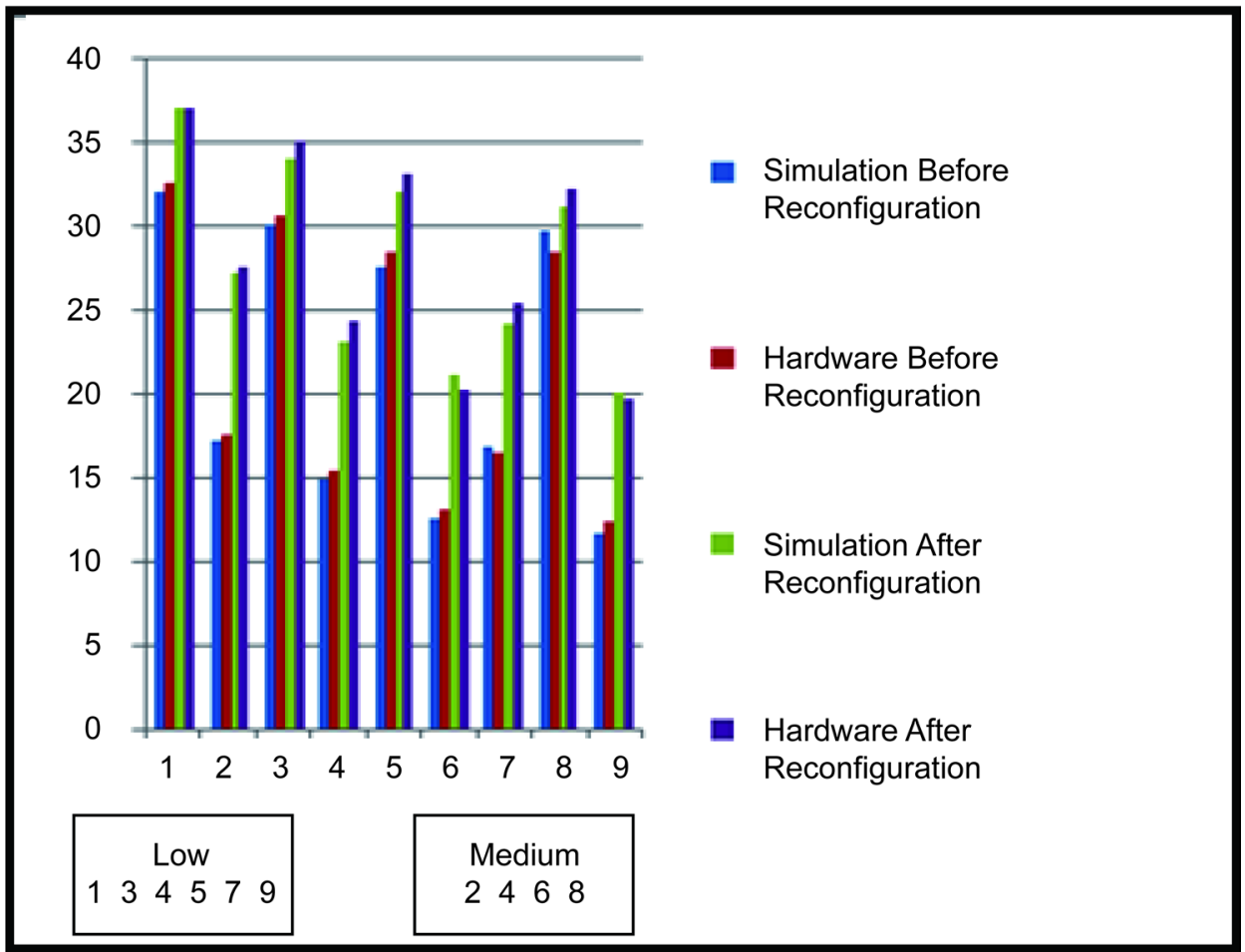

Figure 6. Comparison of results.

In practical setup, partial shading fault is created by hiding the panels in the array by cardboard sheet. The obtained practical results are on par with the simulation results.

\section{Conclusions}

This paper clearly explains the proposed health monitoring system for $2 \times 2 \mathrm{PV}$ array. The method finds the health status once in every 30 minutes from morning $6.00 \mathrm{am}$ to evening $6.00 \mathrm{pm}$. The main advantages of the proposed method are 
- Accurate fault detection

- Classifying the faulty

- Energy extraction improvement

- Extendable for any type of arrays

The reconfigured control switch can be implemented to maximize the power generation under the faulty conditions for the proposed system.

\section{References}

[1] Mahendran, M., Anandharaj, V., Vijayavel, K. and Prince Winston, D. (2015) Permanent Mismatch Fault Identification of Photovoltaic Cells Using Arduino. ICTACT Journal on Microelectronics, 1, 79-82. http://dx.doi.org/10.21917/ijme.2015.0014

[2] Jeba Singh, O. and Prince Winston, D. (2014) A Survey on Classification of Power Quality Disturbances in a Power System. Journal of Engineering Research and Applications, 4, 80-84.

[3] Sakthivel, K. and Prince Winston, D. (2014) Application of Optimization Techniques in Smart Grids. International Journal of Science, Engineering and Technology Research (IJSETR), 3, 32-36.

[4] Prince Winston, D. and Merlin, Ms. (2014) Fuzzy Logic Based Control of a Grid Connected Hybrid Renewable Energy Sources. International Journal of Scientific \& Engineering Research, 5, 1043-1048.

[5] Ramaprabha, R. and Mathur, B.L. (2009) Impact of Partial Shading on Solar PV Module Containing Series Connected Cells. International Journal of Recent Trends in Engineering, 2, 56-60.

[6] Manikandan, P., Neviya, V., Ganesan, L.J. and Prince Winston, D. (2014) Experimental Analysis of Total Harmonic Distortion by Applying Various PWM Techniques on Three Phase Squirrel Cage Motor. International Journal of Research in Computer Applications and Robotics, 2, 82-92.

[7] Vaidya, V. and Wilson, D. (2013) Maximum Power Tracking in Solar Cell Arrays Using Time-Based Reconfiguration. Renewable Energy, 50, 74-81.

http://dx.doi.org/10.1016/j.renene.2012.06.001

[8] Alsayid, B.A., Alsadi, S.Y., Jallad, J.S. and Dradi, M.H. (2013) Partial Shading of PV System Simulation with Experimental Results. Smart Grid and Renewable Energy, 4, 429-435. http://dx.doi.org/10.4236/sgre.2013.46049

[9] Ganesh Raja, B. and Prince Winston, D. (2014) Design and Simulation of Multilevel Inverter Suitable for Grid Connected Photovoltaic System. Advances in Electronic and Electric Engineering, 4, 31-40.

[10] Potnuru, S.R., Pattabiraman, D., Ganesan, S.I. and Chilakapati, N. (2015) Positioning of PV Panels for Reduction in Line Losses and Mismatch Losses in PV Array. Renewable Energy, 78, 264-275. http://dx.doi.org/10.1016/j.renene.2014.12.055

[11] Praveen, S. and Prince Winston, D. (2014) Protection and Performance Improvement of a Photovoltaic Power System. Advances in Electronic and Electric Engineering, 4, 41-48.

[12] Ramaraj, R., Pounraj, P., Prince Winston, D., SakthiSuriya Raj, J.S. and Cynthia Christabel, S. (2015) Analysis of PV Power Generation under Partial Shading and Hotspot Condition. International Journal of Applied Engineering Research, 10, 3443-3447.

[13] Zhou, T.P. and Sun, W. (2015) Study on Maximum Power Point Tracking of Photovoltaic Array in Irregular Shadow. Electrical Power and Energy Systems, 66, 227-234. 
http://dx.doi.org/10.1016/j.ijepes.2014.10.030

[14] Sakthi Suriya Raj, J.S., Pounraj, P., Prince Winston, D., Ramaraj, R. and Cynthia Christabel, S. (2015) Intelligent MPPT Control Technique for Solar PV System. International Journal of Applied Engineering Research, 10, 3386-3391.

Submit or recommend next manuscript to SCIRP and we will provide best service for you:

Accepting pre-submission inquiries through Email, Facebook, LinkedIn, Twitter, etc. A wide selection of journals (inclusive of 9 subjects, more than 200 journals)

Providing 24-hour high-quality service

User-friendly online submission system

Fair and swift peer-review system

Efficient typesetting and proofreading procedure

Display of the result of downloads and visits, as well as the number of cited articles Maximum dissemination of your research work

Submit your manuscript at: http://papersubmission.scirp.org/ 